\title{
The Opioid Epidemic - A Generation in Crisis
}

\author{
Oliver Morgan* \\ University of Scranton (PA, USA)
}

Submission: April 04, 2017; Published: April 13, 2017

*Corresponding author: Oliver Morgan, University of Scranton (PA, USA), Jefferson \& Linden Streets Scranton, PA 18510, USA, Tel: 5708157024; Email: morgano1@scranton.edu

\section{Opinion}

On March 29, 2017 President Donald Trump tapped Governor Chris Christie of New Jersey to lead a commission fighting the opioid addiction crisis. Not a bad choice, as political appointments go. Christie's heartfelt words about addiction went viral in 2015 during the presidential campaign and won him praise. In his last year as governor, Christie has pursued enlightened policies to help stem the tide of opioid and other drug addiction in New Jersey. He has signed legislation limiting first-time narcotic prescriptions to five days' worth of opioids, and requiring health insurers to cover at least a minimum of six months of substance abuse treatment.

In making this announcement, the President mentioned the rise of this current crisis over the last 8 - 10 years. The time frame was accurate. Just about everything else he said was unfortunate, however. He devoted his remarks almost entirely (and incorrectly) to the use of illegal drugs obtained from across the southern border. This emphasis is consistent with his campaign rhetoric and suggests where he wants the new commission to focus its energies. The language, however, echoes themes from older myths and biases. Yale University social historian David Musto was the leading scholar on drug use and the challenges of opioid addiction in the U.S. until he died on October 8, 2010. He was a genial and learned man. His major book, The American Disease: Origins of Narcotic Control, first published in 1973 and re-issued many times, argued for a recurring historical timeline of drug concerns, cycling from periods of societal unease with opioids to concerns about stimulants, and back again, and facing the not-too-subtle racism and xenophobia involved in our cultural concerns about drugs. Drug threats are too often associated in the American imagination with certain suspect groups by race or class - opium and Chinese railroad workers in the late 1800s, marijuana and Mexican immigrants in the early 1900s, cocaine and Black men in the mid-twentieth century South- while this language often exacerbates the social problems we see and offers no real solutions. The President's language is freighted with the same problems.
In our current environment, three observations seem relevant. First, the opioid crisis is not simply about drugs, illegal or legal. Drugs by themselves do not cause addiction. They do "have what it takes" for dependence - a pharmacological notion - just like Zoloft, Clonidine, and steroids do, but not addiction. Addiction requires something added: pathological pursuit of reward or relief, impaired control, craving, continued use despite negative consequences. Concentrating on the chemical composition and effects of certain drugs misses the point, and narrows our perspective to chasing false culprits for addiction. How, for example, do we explain the same dynamics when they involve gambling, or internet gaming? And in any case the opioid crisis now involves heroin and OxyContin with the rising star of the synthetic opioid, fentanyl, not an across the border commodity.

Second, the opioid crisis is not about immigration. Immigrants, legal or illegal, are not the vectors of this health crisis, as though they are modern day "pushers." The myth of the dangerous immigrant, corrupting our culture, is an old trope in American history, but is not applicable here. Patients in the "hot zones" where the opioid crisis looms large - New Hampshire, Ohio, West Virginia, Kentucky, Pennsylvania, and many rural communities across the country are not getting their drugs from illegal immigrants. This is largely Trump Country where immigrants are not all that welcome. Third, the crisis cannot be resolved by focusing on the drugs themselves or providers, whether those providers are immigrants or dealers, physicians or drug companies. Although interdiction, and drug courts, and wiser prescription policies, and renewed bio-research, and enlightened insurance coverage are all part of the solution, we need to think more broadly and deeper about the problem.

By all means we must focus on compassion and care for those directly affected and for those who love them. The opioid crisis is, first and foremost, a human tragedy. Care for our neighbors should be front and center. If, however, we take a wider angle and longer-term view of the challenge, two things come into stark focus. 
I. There is now very good evidence that underneath our addiction challenges lie the societal problem of childhood adversity. A recent New England-based study released by Brown University School of Medicine, Adverse Childhood Experiences in an Opioid Dependent Population, reached several important conclusions. Not only do opioid dependent persons have higher rates of childhood adversity than the general population, but adversity is associated with earlier ages of drug initiation and greater risk of injection drug use and overdose. In addition, childhood trauma, measured by scores on the Adverse Childhood Experiences questionnaires, can be correlated with the severity of opioid dependence.

Clearly we need more and better research into the societal dimensions of childhood adversity and trauma as a powerful and hidden engine of opioid and other drug addiction. A narrow focus on drugs, or providers, or users is not sufficient; we must examine the cultural and social underpinnings of addiction.
II. The other engine underneath widespread addiction is an experience of disconnection and cultural fragmentation. Canadian psychologist Bruce K. Alexander has pioneered such a penetrating analysis in his book, The Globalization of Addiction: A Study in Poverty of Spirit (Oxford, 2008). The cultural conditions for addiction are widespread today and the victims, whether they are in Trump Country or urban ghettoes, may be like "canaries in the coal mines," signaling danger for all of us.

We must undertake robust social research to understand the full dimensions of the problem. In a forthcoming book, Tending Hungry Hearts: A Vital New Clue for Unlocking The Secrets of Addiction, I will undertake such a research project and integrate it with current science and social science based knowledge. I hope you will look forward to it.
Your next submission with Juniper Publishers will reach you the below assets

- Quality Editorial service

- Swift Peer Review

- Reprints availability

- E-prints Service

- Manuscript Podcast for convenient understanding

- Global attainment for your research

- Manuscript accessibility in different formats

( Pdf, E-pub, Full Text, Audio)

- Unceasing customer service

Track the below URL for one-step submission https://juniperpublishers.com/online-submission.php 